\title{
がん検診の最新の動向 :
}

科学的根拠に基づくがん検診について

\author{
東北大学大学院医学系研究科長・医学部長 \\ 東北大学大学院医学系研究科外科病態学講座腫瘍外科学分野 教授 \\ 大内 憲明
}

我が国のがん検診は健康増進法に基づく市町村の事業として行われている。「がん予防重点教育及び がん検診実施のための指針」（平成20年 3 月31日付健発第0331058号厚生労働省健康局長通知）を定め、 市町村によるがん検診を実施している。また、がん検診受診率向上に向けて平成21年度よりがん検診 無料クーポンと検診手帳の配布や、企業との連携の促進等の取組を行っている。しかしながら、がん 検診については、科学的根拠に基づくがん検診について十分でないこと、検診受診率も依然として諸 外国に比して低いことが指摘されている。

厚生労働省は平成15年12月から平成 20 年 3 月まで「がん検診に関する検討会（座長：坦添忠生）を 設置し、各種がん検診の検討を重ね、5大がん（胃がん、子宮がん、肺がん、乳がん、大腸がん）に ついて表 1 のように指針として提言された。

表 1. 市町村事業におけるがん検診（指針の内容）

\begin{tabular}{|l|l|l|l|}
\hline \multicolumn{1}{|c|}{ 種 類 } & \multicolumn{1}{|c|}{ 検 査 項 目 } & \multicolumn{1}{|c|}{ 対象者 } & \multicolumn{1}{c|}{ 診間隔 } \\
\hline 乳がん検診 & 問診、乳房エックス線検査（マンモグラフィ)、視診、触診 & 40 歳以上 & 2 年に 1 回 \\
\hline 子宮がん検診 & 問診、視診、子宮䅡部の細胞診及び内診 & 20 歳以上 & 2 年に 1 回 \\
\hline 大腸がん検診 & 問診、便潜血検査 & 40 歳以上 & 年 1 回 \\
\hline 胃がん検診 & 問診、胃部エックス線検査 & 40 歳以上 & 年 1 回 \\
\hline 肺がん検診 & 問診、胸部エックス線検査、喀痰細胞診 & 40 歳以上 & 年 1 回 \\
\hline
\end{tabular}

その後 4 年以上が経過し、日本のがん対策のための戦略研究「超音波検査による乳がん検診の有効 性を検証する比較試験 J-START」や、US Preventive Services Task Forceによる40歳代マンモグラ フィー検診の見直し、HPV ワクチンによる子宮がん予防対策等、諸外国においてもがん検診に関する 新たなデー夕に基づく指針の見直しが図られている。また、二期目のがん対策基本計画において科学 的根拠に基づくがん検診の確実なる実施が求められていることから、平成24年度に、改めて厚生労働 省内に「がん検診の在り方に関する検討会（座長：大内憲明）」が設置された。本検討会では、国内外 の最新の試験を収集し、科学的根拠のあるがん検診の方法等、及び受診率向上施策について、これま での施策の効果を検証した上で、より効率的・効果的な施策等を検討する。

がんによる死亡率を減少させるのが検診の目的であり、最も大切なことは、科学的根拠に基づくが ん検診を実施することである。さらに、精度管理を徹底し、受診率を上げていくことが重要である。 本検討会では、新しい知見を踏まえた各種がんの検診の検査項目、精度管理の在り方、並びに受診率 向上施策（無料クーポン券の活用を含む）について検討を重ねる事になる。 